\title{
Strengthening Character Education through Outbound Learning on Elementary School Students
}

\author{
Ika Candra Sayekti ${ }^{1}$, Rusnilawati $^{2}$, Almuntaqo Zainuddin ${ }^{3}$, Fitri Puji Rahmawati ${ }^{4}$, Risky Kartika ${ }^{5}$, \\ Wahdan Najib Habibi ${ }^{6}$ \\ \{ics142@ums.ac.id ${ }^{1}$,rus874@ums.ac.id², az123@ums.ac.id ${ }^{3}$, fpr223@ums.ac.id ${ }^{4}$, \\ kartikarisky61@gmail.com ${ }^{5}$,wnh122@ums.ac.id $\left.{ }^{6}\right\}$ \\ Universitas Muhammadiyah Surakarta ${ }^{1,2,3,4,5,6}$
}

\begin{abstract}
The objective of this research was to identify the character education building through outbound learning at Muhammadiyah Alam Surya Mentari Elementary School in Surakarta. The method used in this research was descriptive qualitative. The data were collected through observation, interview, and documentation. Observation was carried out in learning process. Interview was conducted by questioning the teachers and the headmaster. Documentation was obtained by collecting various supporting documents. This research took place at Muhammadiyah Alam Surya Mentari Elementary School in Surakarta. Triangulation methods, namely triangulation of sources and techniques, were used to validate the data. The results of this research show that: (1) characters education building is integrated in outbound learning; (2) there are five core values of character that can be developed through outbound learning, those are: religiosity, nationalism, cooperation, integrity, and self-dependence.
\end{abstract}

Keywords: characteristic education, elementary school, outbound learning

\section{Introduction}

In accordance with Presidential Decree no. 87 of 2017 [1] on Strengthening Character Education in Indonesian this term is well known by PPK, character education is necessary to create a cultured nation by strengthening the values of religiosity, honesty, tolerance, discipline, hard work, creativity, democracy, curiosity, patriotism, nationalism, appreciation of achievement, communicative-competency, pacifism, reading fondness, social responsibility, and responsibility in general. PPK plays an important and strategic role in planning character revolution of a nation, as stated in Nawacita, which is to encourage National Movement of Mental Revolution [2]. PKK is an educational movement aimed to strengthen students' characters at school through the harmonization of emotional training (olah hati), will training (olah rasa), mind training (olah pikir), and physical training (olah raga) supported by public participation and cooperation of school, family, and society [3].

PPK aims to: (1) build and equip students, as the Indonesia 2045 Golden Generation, with the spirit of Pancasila and good character education to challenge the dynamic of change in the future; (2) develop national education platform that puts character education as the main spirit in education administration for students, supported by public participation that consider the cultural diversity in Indonesia; and (3) revitalize and strengthen the potential and competency of educators, staffs, students, society, and family environments in implementing PKK [1]. 
Seeing this noble goal, the promotion of PKK shall be supported by each part of society in order to create a generation with good character and is able to survive in its era.

Moreover, the urgency of character education is important to help students develop their positive characters to improve their quality as human beings; to promote character development through ethics integrated into curriculum; to develop a positive moral climate by involving students, teachers, staff, parents, and communities; to teach students to handle a conflict justly; to create a safer school; to reassure; to teach students and adults to understand, participate, care, act ethically and justly, be responsible to themselves and others at school and in a bigger communities [4].

PPK also answers the challenge facing this nation, in which there are many cases found related to the low character of students in formal education field, such as: death of a teacher killed by his own student [5]; theft done by an elementary school student [6]; a junior high school student getting pregnant by an elementary school student [7], etc. This situation is quite alarming, since PPK has actually been integrated into RPJMN 2015-2019: "Strengthening character education on students from all levels of education to reinforce their moral values, character, and personality by strengthening character education integrated into curriculum" [8]. However, we can still find many facts about students with low character. Such problem becomes homework in education, especially school as the second home for student, since superior generation should be started from good characters. Those characters will shape a whole, principled, and civilized human.

Other challenges facing this character building are complex, such as: (1) the large numbers of students, teachers, and schools in Indonesia; (2) the synergy between schools, parents, and communities that have not been maximized yet; (3) inevitable globalization challenges. School as a formal education provider is not the only organization involved in character building, but it definitely plays huge role in shaping strong character on its students. It is in line with the opinion of Agboola and Chen [9], that character education does not immediately functions in justifying student's deviant behavior since there are other factors influencing it, such as: family, social environment, and cultural issue. One thing that school can do is integrating character building through PPK into intracurricular, hidden-curricular, and extracurricular activities that are able to synergize four dimensions of Ki Hajar Dewantara character processing, which are physical training, mind training, will training, and emotional training.

Considering the importance of PPK and challenges facing by this nation, it is necessary to understand the extent to which PPK is implemented at school. One of many activities that can synergize Ki Hajar Dewantara character processing is outbound. Ganet [2] stated that outbound is a joyful outdoor activity with games; which contains philosophy, life simulation, mind training, study case, role play, and direct practice using experience (experiential learning) as an approach. Learning process will more effective and yield a good effect if the learning process conducted by various activity, such as in outdoor or outdoor learning. When engaged in outdoor activities, students are more likely to protect the environment [10]. Outdoor play also important for children's social emotional, physical development, and social emotional [10]. One of outdoor learning can be conducted through outbound learning

According to Susanta [11], the advantages of outbound are to: (1) train mental endurance and self-control; (2) grow empathy; (3) encourage healthy competition; (4) improve leadership skills; (5) understand that one's weakness is not an obstacle; (6) improve decision-making skill in a difficult situation quickly and accurately; (7) grow self-confidence; (8) increase the sense of need in team cooperation to reach a target optimally; (9) narrow the gap between new and old friends and strengthen solidarity; (10) promote unyielding attitude and self-confidence; (11) train social skills; (12) improve skills on knowing one's own self and other people. Considering 
those advantages mentioned above, we are interested in doing research on character building through outbound at school. One of the schools that implements outbound learning as its learning subject is SD Muhammadiyah Alam Surya Mentari.

According to Presidential Decree no. 87 of 2017 [1], strengthening character can be done by internalizing the key values of PPK; namely religiosity, nationalism, self-dependence, cooperation, and integrity in each learning activity. Religiosity includes: having faith and devotion to The One Almighty God, performing religious services diligently, being grateful, praying before and after doing activities, etc. Nationalism includes: patriotism, having spirit of nationality, respecting differences, embracing national and folk songs, loving Indonesian products, pacifism, willingness to sacrifice, obeying the regulations, etc. Self-dependence includes: being discipline, confident, curious, tough, hard worker, independence, creative, innovative, lifetime learner, etc. Cooperation includes: helping others; willingness to cooperate; taking care of each other; being considerate; protecting the environment, cleanliness, and tidiness; having spirit of kinship; participating actively in social activities, etc. Integrity includes: being honest, humble, polite, responsible, precedent, morally committed, righteous, true to one's own word, uncorrupted, etc. The key value indicators in this research are limited to: religiosity, that includes: having faith and devotion to The One Almighty God, performing religious services diligently, being grateful, praying before and after doing activities, etc. Nationalism, that includes: patriotism, having spirit of nationality, respecting differences, embracing national and folk songs, loving Indonesian products, keeping peace, obeying the regulations, etc. Self-dependence, that includes: being discipline, confident, curious, tough, hard worker, independence. Cooperation, that includes: helping others; willing to cooperate; taking care of each other; being considerate; protecting the environment, cleanliness, and tidiness; as well as having spirit of kinship. Integrity, that includes: being honest, humble, polite, responsible, righteous, always true to one's own word.

SD Muhammadiyah Alam Surya Mentari is a school of nature that implements the basic concept of character building on its students through outbound learning. The outbound is held every day at SD Muhammadiyah Alam Surya Mentari with an adjustment to class learning schedule.

The objective of this research was to identify the character strengthening through the outbound learning at SD Muhammadiyah Alam Surya Mentari.

\section{Method}

This research applied a qualitative method.

\subsection{Research Location and Period}

This research took place at SD Muhammadiyah Alam Surya Mentari located on Jl. Mangga no.6, Surakarta. This research was carried out from February 2018 until June 2018.

\subsection{Data}

The data in this research were information collected from the informants; namely the headmaster, the outbound teacher, and the students related to the research problem.

\subsection{Data Collection Techniques}

The data in this research were collected through observation, interview, and documentation. Observation is an act of collecting field notes [12]. The observation was carried out by observing and taking notes on the students as the object of this research during outbound learning to understand how the teacher strengthened the character education, how was the development, and 
what kinds of characters were able to be strengthened. Qualitative interview happens when a researcher is asking various open questions to participants and taking notes on their answers [12]. The interview was used in relation with the outbound learning process, the implementation of strengthening character education through outbound learning, and the variety of characters that could be strengthened in outbound learning. The documentation used in this research were lesson plan and other documents.

\subsection{Data Analysis Technique}

This research used interactive analysis consisted of three components: data reduction, data presentation, and conclusion drawing or verification. Those three components were interweaving and conducted continuously in the process of Milles and Huberman data collection.

\subsection{Data Validation}

Triangulation research is used to understand how valid certain data are. Triangulation is defined as a data collection technique that combines various techniques and available sources [13]. In this research, there were two type of triangulations used: technique triangulation and source triangulation.

\section{Result And Discussion}

SD Muhammadiyah Alam Surya Mentari's vision is to: "become a nature-oriented educational institution with healthy environmental insight to prepare a generation with good morals, strong characters, extensive knowledge, and excellent achievement. Meanwhile, the missions are to: (1) Organize a high quality nature-oriented education in developing logical sense through optimal interaction with nature to thank God for His creation, (2) Grow empathy for living environment and surrounding nature; (3) Prepare student to be a human being with strong character that is honest, polite, brave, and caring; (4) Develop a comprehension and implementation of Islamic values to become a khalifatul fil ardhi; (5) Become a generation with entrepreneurship that is ready to compete in global era (6) Optimize guiding effort on student to result in high quality, competitive, and productive output.

SD Muhammadiyah Alam Surya Mentari aims to: (1) Improve religious learning practice and accustom students on noble manners; (2) improve its teachers and staff quality; (3) prepare a generation with self-dependence, responsibility, and high compassion on nature and any God's creatures; (4) grow entrepreneurship; (5) tighten relationship with school committee to improve the questioning role in educational administration. The above-mentioned vision, missions, and objectives show that SD Muhammadiyah Alam Surya Mentari supports government movement on character. The support is generated into PPK-based school activities. One of the activities that is in line with PPK is outbound learning intracurricular. This finding is supported by the results of the study of Buchori [14] that outbound activities are effective in increasing honesty and integrity. Outbound learning can build understanding of concepts and build individual character behavior. The character is well embedded and students can become better personalities.

The implementation of character education at SD Muhammadiyah Alam Surya Mentari is derived from school's vision and mission. Since SD Muhammadiyah Alam Surya Mentari aims to make their students human beings with strong characters, as a kholifah fil ard, the students are taught to prioritize character education. The intention is that the students are able to live in their times in accordance with the provisions of Allah SWT. When they understand their identity as human beings that should protect, preserve, develop, and utilize the universe; they are expected to possess strong and noble characters, and are able to be future leaders. In accordance with the opinion Machsunah [15] that character education from an early age is very important. Character education is provided through exemplary educators in the school environment. 
The implementation of character education in SD Muhammadiyah Alam Surya Mentari is started from the four main characters, which are integrative implemented on activities inside and outside the class, even outside the school. When learning in class, students are emphasized to learn well by implementing the four main characters--brave, honest, caring, and polite-- which are the slogan of this school. Whereas, character education outside the class is implemented through outbound learning.

Outbound learning is integrated as a subject given to students in grade I to V once a week, designed by the outbound teacher by adjusting it to the learning topic in each class. This outbound becomes a subject that is used as a medium to develop and shape students' mental and attitude. Outbound learning is taught in fun ways and leave impression for students. Outbound is a way or method to develop bonding and care about friends and environment. This is in line with an expert's opinion, that outbound is a joyful outdoor activity with games; which contains philosophy, life simulation, mind training, study case, role play, and direct practice using experience (experiential learning) as an approach [2] and outbound is able to improve creativity and cooperation among the students in elementary students [16].

Outbound learning at SD Muhammadiyah Alam Surya Mentari acts as a medium to manifest school pillars--braveness, honesty, politeness, and caring for others-- in accordance to the school of nature's motto. Those pillars become basis in developing students' characters in this school.

Meanwhile, outbound aims to: (1) identify the students' strengths and weaknesses; (2) uplift their spirit and motivate them to be continuously involved in activities; (3) promote selfdependence and act according to their will; (4) grow empathy and sensitivity to others' feeling; (5) build communication skill; (6) be a medium to learn effective and creative communication; (7) engraft positive values to shape character through various real-life examples; (8) implement and give examples on good character to environment. This finding is reinforced by Hakim and Kumala [2] that students need positive activities to develop their talents and abilities in all fields. Outbound activities can provide learning for students to have good character. Outbound activities have a direct impact on the formation of morals and character so that it can improve the quality of education. In addition, outbound activities require teamwork and mutual trust between children. This can encourage children to be able to interact with other people [17]. Outbound can be a teacher's effort in developing children's social maturity.

The achievement of character building was determined from the indicators shown by the students through outbound learning. The following table shows the character building appeared from the activity.

Table 1. Character Building in Outbound Learning

\begin{tabular}{|c|c|c|}
\hline $\begin{array}{l}\text { Main } \\
\text { Value }\end{array}$ & Aspect & Outbound Activity \\
\hline Religiosity & $\begin{array}{l}\text { having faith and devotion to The } \\
\text { One Almighty God, performing } \\
\text { religious services diligently, being } \\
\text { grateful, praying before and after } \\
\text { doing activities, etc. }\end{array}$ & $\begin{array}{l}\text { 1. Praying before the class starts } \\
\text { 2. Praying after the class ends } \\
\text { 3. Giving and answer greeting } \\
\text { 4. Thanking God after successfully doing } \\
\text { something }\end{array}$ \\
\hline Nationalism & $\begin{array}{l}\text { patriotism, having spirit of } \\
\text { nationality, respecting differences, } \\
\text { embracing national and folk } \\
\text { songs, loving Indonesian products, } \\
\text { keeping peace, obeying the } \\
\text { regulations, etc. }\end{array}$ & $\begin{array}{l}\text { 1. Playing puzzle of heroes } \\
\text { 2. Knowing heroes name and their homelands } \\
\text { 3. Speaking in good and proper Indonesian } \\
\text { 4. Not fighting } \\
\text { 5. Not blaming others when lose } \\
\text { 6. Shaking hands after playing }\end{array}$ \\
\hline
\end{tabular}




\begin{tabular}{|c|c|c|}
\hline $\begin{array}{l}\text { Self- } \\
\text { dependence }\end{array}$ & $\begin{array}{l}\text { being discipline, confident, } \\
\text { curious, tough, hard worker, } \\
\text { independence. }\end{array}$ & $\begin{array}{l}\text { 1. Wearing outbound uniform } \\
\text { 2. Finish playing on time } \\
\text { 3. Obeying game rules and regulation } \\
\text { 4. Following rules orderly } \\
\text { 5. Being brave to perform in front of friends } \\
\text { and teacher } \\
\text { 6. Getting interested in trying a game } \\
\text { 7. Being enthusiastic on the given game rules } \\
\text { 8. Being happy when trying new game } \\
\text { 9. Willing to playing games or obstacle until } \\
\text { the end } \\
\text { 10. Engaged in healthy competition } \\
\text { 11. Willing to put in the utmost effort to get } \\
\text { the best result } \\
\text { 12. Playing individual/team game } \\
\text { 13. Doing activities with his/her own ability }\end{array}$ \\
\hline Cooperation & $\begin{array}{l}\text { helping others; willing to } \\
\text { cooperate; taking care of each } \\
\text { other; being considerate; } \\
\text { protecting the environment, } \\
\text { cleanliness, and tidiness; as well } \\
\text { as having spirit of kinship. }\end{array}$ & $\begin{array}{l}\text { 1. Developing bonding between student's own } \\
\text { and opposing team } \\
\text { 2. Helping injured friend } \\
\text { 3. Cleaning environment together } \\
\text { 4. Throwing garbage in its place } \\
\text { 5. Collecting litter and throw it away after } \\
\text { outbound learning ends }\end{array}$ \\
\hline Integrity & $\begin{array}{l}\text { being honest, humble, polite, } \\
\text { responsible, righteous, always } \\
\text { true to one's own word. }\end{array}$ & $\begin{array}{l}\text { 1. Playing according to the rules } \\
\text { 2. Maintaining score point } \\
\text { 3. Saying the truth } \\
\text { 4. Admitting mistakes } \\
\text { 5. Admitting weakness } \\
\text { 6. Admitting friends' strengths } \\
\text { 7. Being humble after winning a game } \\
\text { 8. Playing well } \\
\text { 9. Finishing game on time } \\
\text { 10. Disciplining team member (for team } \\
\text { leader) } \\
\text { 11. Being responsible for all of his/her own } \\
\text { actions }\end{array}$ \\
\hline
\end{tabular}

According to the table 1, it shows that character building through outbound learning is able to penetrate the main values of PPK and when this activity continues, those characters are able to internalized well in each student. This finding is reinforced by Agung [18] that Character Education not only intends to instill, shape, and direct the behavior of students who are moral, noble, virtuous, and civilized, but also the ability to anticipate, be responsive, and be adaptive to developments and changes in the global environment.

\section{Conclusion}

The results of this research are: (1) characters education building is integrated in outbound learning; (2) there are five core values of character that can be developed through outbound learning, those are: religiosity, nationalism, cooperation (gotong royong), integrity, and selfdependence. 


\section{References}

[1] Peraturan Presiden RI, Penguatan Pendidikan Karakter. Indonesia, 2017.

[2] A. R. Hakim and F. N. Kumala, "Pengembangan Karakter melalui Kegiatan Outbound," J. Moral Kemasyarakatan, vol. 1, no. 2, pp. 173-182, 2016.

[3] Kemendikbud RI, “Konsep Dasar Penguatan Pendidikan Karakter,” Jakarta, 2016.

[4] A. Pala, "The Need For Character Education," Int. J. Soc. Sci. Humanit. Stud., vol. 3, no. 2, pp. 1309-8063, 2011.

[5] E. Damhuri, "Tewasnya Guru Budi Jadi Pintu Masuk Penguatan Karakter Siswa," Harian Republika, Jakarta, 07-Feb-2018.

[6] Kurniawan, "Pencurian Sragen: Sudah Sekolah Lagi, Begini Kabar 2 Siswa SD Curi Motor," Solopos.com, 2018. [Online]. Available: https://www.solopos.com/pencuriansragen-sudah-sekolah-lagi-begini-kabar-2-siswa-sd-curi-motor--910320.

[7] W. Slamet, "Siswa SD Hamili Siswi SMP, Usia Kandungan Sudah 6 Bulan," Harian Kompas, Jakarta, May-2018.

[8] Minister of National Development Planning RI, The Strategic Plan of The Ministry of National Development Planning of 2015-2019. Indonesia, 2017, p. 68.

[9] A. Agboola and K. C. Tsai, "Bring Character Education Into Classroom," Eur. J. Educ. Res., vol. 1, no. 2, pp. 163-170, Apr. 2012.

[10] K. Burriss and L. Burriss, "Outdoor Play and Learning: Policy and Practice," Int. J. Educ. Policy Leadersh., vol. 6, no. 8, pp. 1-12, 2011.

[11] N. S. Isbayani, N. M. Sulastri, and L. A. Tirtayani, "Penerapan Metode Outbound untuk Meningkatkan Keterampilan Sosial Emosional Anak," J. Pendidik. Anak Usia Dini Undiksha, vol. 3, no. 1, 2015.

[12] J. W. Creswell, Riset Pendidikan, Perencanaan, Pelaksanaan, dan Evaluasi Riset Kualitatif. Yogyakarta: Pustaka Pelajar, 2015.

[13] Sugiyono, Memahami Penelitian Kualitatif. Bandung: Alfabeta, 2005.

[14] S. Buchori, M. Ibrahim, and A. Saman, "Pengaruh Character Education Training melalui Outbound Training untuk Peningkatan Kejujuran dan Integritas," J. Psikol. Pendidik. Konseling, vol. 2, no. 1, pp. 12-19, 2016.

[15] Y. C. Machsunah, "Penanaman Pendidikan Karakter melalui Keteladanan Pendidik (Studi Kasus di LBB Taman Pintar; Sahabat Sekolah Anak Lamongan)," J. Ilmu Sos. dan Humaniora, EDUPEDIA, vol. 1, no. 2, pp. 59-65, 2015.

[16] A. R. Agusta, P. Setyosari, and C. Sa'dijah, "Implementasi Strategi Outdoor Learning Variasi Outbound untuk Meningkatkan Kreativitas dan Kerjasama Siswa Sekolah Dasar," J. Pendidik. Teor. Penelitian, dan Pengemb., vol. 3, no. 4, pp. 453-459, Apr. 2018.

[17] T. W. Praktik, "Mengembangkan Kematangan Sosial Pada Anak Melalui Outbond," Sekol. Dasar Kaji. Teor. dan Prakt. Pendidik., vol. 17, no. 2, pp. 143-152, 2008. 
[18] I. Agung, "Peran Fasilitator Guru dalam Penguatan Pendidikan Karakter (PPK)," J. Perspekt. Ilmu Pendidik., vol. 31, no. 2, pp. 106-119, 2017. 